\title{
Grade 1 Endometrioid Carcinoma With an Area of Serous Carcinoma Less than 5\% Is More Aggressive than Stage IA Pure-type Grade 1 Endometrioid Carcinoma
}

\author{
MORIKAZU MIYAMOTO ${ }^{1}$, HITOSHI TSUDA ${ }^{2}$, ATSUSHI SUGIURA ${ }^{3}$, TSUNEKAZU KITA ${ }^{3}$, \\ YOSHITAKA KATAOKA ${ }^{4}$, KENJI ISHII ${ }^{4}$, KAZUYA KUDO ${ }^{5}$, HIROKO MATSUURA ${ }^{1}$, HIROKI ISHIBASHI ${ }^{1}$, \\ HIDEKI IWAHASHI $^{1}$, TAIRA HADA ${ }^{1}$, RIE SUZUKI $^{1}$ and MASASHI TAKANO ${ }^{1}$ \\ ${ }^{1}$ Department of Obstetrics and Gynecology, National Defense Medical College Hospital, Saitama, Japan; \\ ${ }^{3}$ Department of Basic Pathology, National Defense Medical College Hospital, Saitama, Japan; \\ ${ }^{3}$ Department of Obstetrics and Gynecology, Nara Prefecture General Medical Center, Nara, Japan; \\ ${ }^{4}$ Department of Gynecology, Nishisaitama-chuo National Hospital, Saitama, Japan; \\ ${ }^{5}$ Department of Gynecology, Tama-Hokubu Medical Center, Tokyo, Japan
}

\begin{abstract}
Background/Aim: In 2020, the percentages were removed from the World Health Organization's criteria for mixed carcinoma. The aim was to examine the clinical significance of an area of serous carcinoma (SC) $<5 \%$. Patients and Methods: Our study included 236 patients with the 2009 International Federation of Obstetrics and Gynecology (FIGO) stage IA grade 1 endometrioid carcinoma (EG1) from multiple hospitals. EG1 patients with an area of $S C<5 \%$ and those with pure-type EGl were retrospectively compared. Results: In the multivariate analysis for recurrence, an area of $S C<5 \%$ was an independent risk factor [hazard ratio $(H R)=101.51, p<0.01]$. In the multivariate analysis for progression-free survival, an area of $S C<5 \%$ was identified as a negative prognostic factor $(H R=62.43, p<0.01)$. Conclusion: EGl with an area of $S C<5 \%$ may be more aggressive than pure-type EG1 at FIGO stage IA.
\end{abstract}

The incidence rate of endometrial carcinoma has been increasing worldwide (1). Among several histological subtypes of endometrial endometrioid carcinomas, grade 1 endometrioid carcinoma (EG1) of stage IA, as defined by the 2009 International Federation of Obstetrics and Gynecology

This article is freely accessible online.

Correspondence to: Morikazu Miyamoto, Department of Obstetrics and Gynecology, National Defense Medical College Hospital, 3-2, Namiki, Tokorozawa, Saitama, 359-8513, Japan. Tel: +81 429951687, Fax: +81 429965213, e-mail: mmiyamoto@ndmc.ac.jp

Key Words: Endometrial carcinoma, endometrioid carcinoma, serous carcinoma, mixed carcinoma, World Health Organization criteria.
(FIGO), has the highest incidence $(31.7 \%)$, with 5-year survival rates ranging from $92.3 \%$ to $93.7 \%$ (2).

The standard therapy for endometrial carcinoma has been a hysterectomy and bilateral salpingo-oophorectomy, followed by adjuvant treatment or observation. The indication for adjuvant therapy has been based on recurrence risk classification (3). Some reports have demonstrated that EG1 at FIGO stage IA should be classified as low risk, regardless of the presence of lymphovascular invasion (4-6). Other reports have suggested that stage IA EG1 without lymphovascular invasion should be considered low risk for recurrence and that carcinomas harboring lymphovascular invasion, as intermediate risk $(7,8)$. Moreover, a systematic review has revealed a recurrence rate of $3 \%$ or less for low-risk patients (grade 1 or 2 , and $\leq$ one-third of myometrial invasion, FIGO stage I) (9). Thus, EG1 at stage IA was classified as low or intermediate risk and regarded as one of the histological types with a relatively low recurrent risk, regardless of lymphovascular invasion.

Endometrial serous carcinoma (SC) is known to be an aggressive subtype, as is mixed carcinoma which includes SC $(10,11)$. According to the 2014 World Health Organization (WHO) criteria, mixed carcinomas had more than $5 \%$ of a second component and were classified as type I or type II tumors (12). However, in the newest 2020 WHO criteria, the terms type I and type II were not used for tumor stratification and mixed carcinoma was defined as carcinoma composed of two or more discrete histological subtypes of endometrial carcinoma, where at least one component was either serous or clear cell, and the variable component was removed because even small foci of serous or clear cell carcinoma were associated with poor outcomes (13).

Our previous study, which used the 2014 WHO criteria, demonstrated that two of the five $(40.0 \%)$ stage $1 \mathrm{~A}$ EG1 
Table I. Characteristics of all patients with grade 1 endometrioid carcinoma at FIGO stage IA according to a $<5 \%$ area of serous carcinoma.

\begin{tabular}{|c|c|c|c|c|c|c|}
\hline \multirow[b]{2}{*}{ Variables } & & \multicolumn{2}{|c|}{$\begin{array}{c}\text { Grade } 1 \text { endometrioid } \\
\text { carcinoma with area of serous } \\
\text { carcinoma }<5 \%\end{array}$} & \multicolumn{2}{|c|}{$\begin{array}{l}\text { Pure-type } \\
\text { grade } 1 \text { endometrioid } \\
\text { carcinoma }\end{array}$} & \multirow[b]{2}{*}{$p$-Value } \\
\hline & & & & & & \\
\hline \multirow[t]{2}{*}{ Age, years } & $<60$ & 2 & $(33 \%)$ & 154 & $(67 \%)$ & 0.18 \\
\hline & $\geq 60$ & 4 & $(67 \%)$ & 76 & $(33 \%)$ & \\
\hline \multirow[t]{2}{*}{ Lymphovascular invasion } & Positive & 2 & $(33 \%)$ & 29 & $(13 \%)$ & 0.18 \\
\hline & Negative & 4 & $(67 \%)$ & 201 & $(87 \%)$ & \\
\hline \multirow[t]{2}{*}{ Peritoneal washing cytology } & Positive & 1 & $(17 \%)$ & 18 & $(8 \%)$ & 0.40 \\
\hline & Negative & 5 & $(83 \%)$ & 212 & $(92 \%)$ & \\
\hline \multirow[t]{2}{*}{ Endocervical glandular involvement } & Positive & 0 & & 11 & $(5 \%)$ & 0.99 \\
\hline & Negative & 6 & $(100 \%)$ & 219 & $(95 \%)$ & \\
\hline \multirow[t]{2}{*}{ Mode of uterine resection } & Extended hysterectomy & 1 & $(17 \%)$ & 89 & $(39 \%)$ & 0.41 \\
\hline & Simple hysterectomy & 5 & $(83 \%)$ & 141 & $(61 \%)$ & \\
\hline \multirow[t]{2}{*}{ Pelvic lymphadenectomy } & Performed & 5 & $(83 \%)$ & 187 & $(81 \%)$ & 0.99 \\
\hline & Not performed & 1 & $(17 \%)$ & 43 & $(19 \%)$ & \\
\hline \multirow{2}{*}{ Para-aortic lymphadenectomy } & Performed & 1 & $(17 \%)$ & 52 & $(23 \%)$ & 0.99 \\
\hline & Not performed & 5 & $(83 \%)$ & 178 & $(77 \%)$ & \\
\hline \multirow[t]{2}{*}{ Adjuvant chemotherapy } & Performed & 0 & & 23 & $(10 \%)$ & 0.99 \\
\hline & Not performed & 6 & $(100 \%)$ & 207 & $(90 \%)$ & \\
\hline \multirow[t]{2}{*}{ Recurrence } & Yes & 3 & $(50 \%)$ & 2 & $(1 \%)$ & $<0.01$ \\
\hline & No & 3 & $(50 \%)$ & 228 & $(99 \%)$ & \\
\hline
\end{tabular}

cases with an area of SC $<5 \%$ recurred, while only one of the $121(1.0 \%)$ stage IA pure-type EG1 patients did (14). Thus, we determined that using the 2014 WHO criteria of an area of SC $<5 \%$ may be useful for predicting the recurrence of stage IA EG1. Furthermore, since EG1 with an area of SC $<5 \%$ was more aggressive than the pure type EG1, it was also valid to categorize it into mixed carcinoma using the 2020 WHO criteria. However, since our previous work was a single-institutional study with a small number of cases, we determined that multi-institutional analyses with many more patients were needed to confirm the results.

Therefore, the purpose of the present study was to examine whether EG1 with an area of SC $<5 \%$ classified as mixed carcinoma according to the 2020 WHO criteria was more aggressive than pure-type EG1 at stage IA according to the 2009 FIGO criteria.

\section{Patients and Methods}

Patients who received total abdominal hysterectomy and bilateral salpingo-oophorectomy for EG1 at stage IA at the National Defense Medical College Hospital (Tokorozawa, Japan), the Nara Prefecture General Medical Center (Nara, Japan), the Nishisaitama-Chuo National Hospital (Tokorozawa, Japan) and the Tama-Hokubu Medical Center (Higashimurayama, Japan) between 1990 and 2015 were included. Central pathological reviews were performed for all patients using the $2020 \mathrm{WHO}$ criteria (M.M. and H.T.) (13). Patients with histological subtypes other than EG1 and those who died of diseases that were not clearly associated with stage IA EG1 were excluded. Among the mixed-type carcinomas, EG1 with an area of $\mathrm{SC}<5 \%$ was identified separately. Other data were obtained from the hospitals' clinical records.

For statistical analysis, we used JMP Pro 14 software (SAS Institute Inc., Cary, NS, USA). The chi-square test and Fisher's exact test for unpaired data were performed. Progression-free survival (PFS) curves were calculated with the Kaplan-Meier method. Survival curve comparisons were performed using the log-rank test. Multivariable analyses for the recurrent factors and PFS were performed using logistic regression and the Cox proportional hazards model, respectively. A $p$-value $<0.05$ was defined as statistically significant.

Our research was conducted ethically in accordance with the Declaration of Helsinki of the World Medical Association. The Institutional Review Board of the National Defense Medical College (Saitama, Japan) approved this study (confirmation no.: 2834). Informed consent was waived due to the retrospective nature of the study; however, we offered an opportunity for the patients to refuse permission for their data to be used via our hospital website.

\section{Results}

The median study period was 60 months. A total of 260 patients were enrolled and underwent a pathological review. Of them, 24 patients were excluded: 6 had no evaluable specimens, 4 were diagnosed with mixed carcinoma types, 5 did not receive bilateral salpingo-oophorectomy, 3 were diagnosed with diseases other than FIGO stage IA, 1 case was complicated with ovarian carcinoma, 1 was diagnosed with SC, 2 were diagnosed with grade 2 endometrioid carcinoma, 1 was dead of cerebral infarction and 1 was 


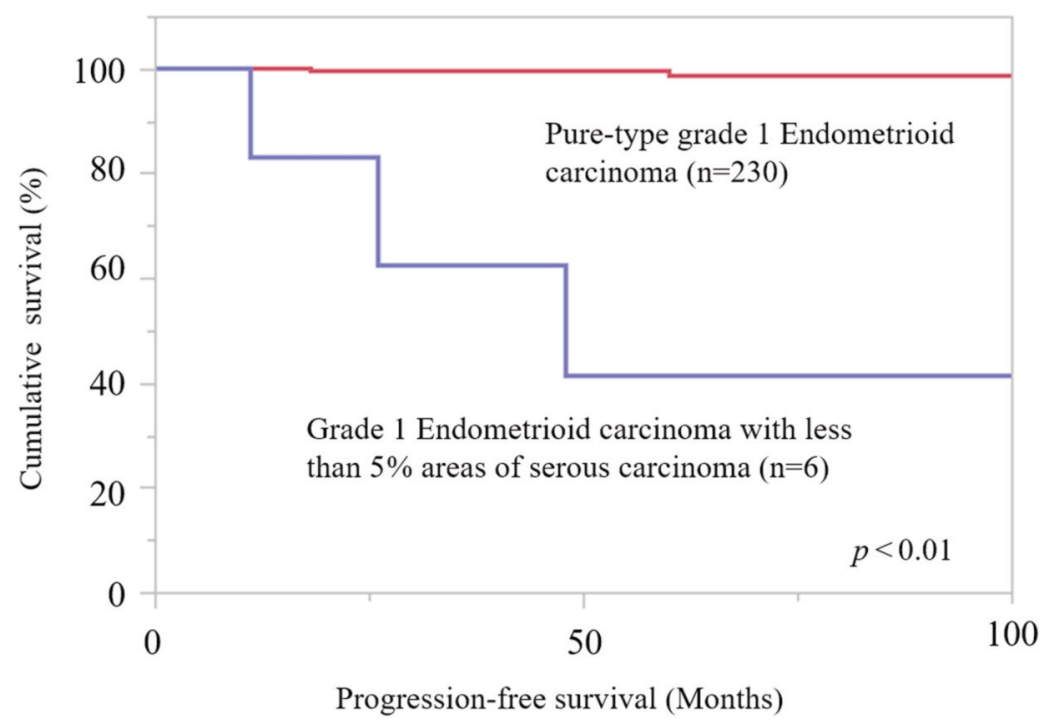

Figure 1. Progression-free survival of patients with grade 1 endometrioid carcinoma (EG1) at stage IA, according to the 2009 International Federation of Obstetrics and Gynecology, with or without a $<5 \%$ area of serous carcinoma.

Table II. Multivariate analysis of recurrence in patients with grade 1 endometrioid carcinoma at FIGO stage IA.

\begin{tabular}{lccc}
\hline Variables & Hazard ratio & $(95 \% \mathrm{CI})$ & $p$-Value \\
\hline $\begin{array}{l}\text { Peritoneal washing cytology } \\
\quad \text { Positive } v s . \text { Negative }\end{array}$ & 2.52 & $(0.11-56.09)$ & 0.56 \\
$\begin{array}{l}\text { Mode of uterine resection } \\
\quad \text { Extended hysterectomy } v s .\end{array}$ & 0.68 & $(0.056-8.35)$ & 0.77 \\
$\quad \begin{array}{l}\text { Simple hysterectomy } \\
\text { Para-aortic lymphadenectomy } \\
\quad \begin{array}{l}\text { Performed } v s . \text { Not performed } \\
\text { Area of serous carcinoma }<5 \%\end{array} \\
\quad \text { Positive } v s . \text { Negative }\end{array}$ & 0.81 & $(0.04-18.07)$ & 0.84 \\
\hline
\end{tabular}

diagnosed with stomach carcinoma. Overall, our study included 236 patients.

Six of the $236(2.5 \%)$ patients had EG1 with an area of $\mathrm{SC}<5 \%$. These patients experienced recurrences more often than patients with pure-type EG1 (50\% vs. $1 \%$, respectively, $p<0.01)$. There were no other statistical differences between both groups (Table I). During the observational period, no patients with areas of SC $<5 \%$ died of the disease and only one patient with pure-type EG1 died. Patients with areas of SC $<5 \%$ had worse PFS than those without (Figure 1) $(p<0.01)$. In Table II, multivariate analysis showed that having areas of $\mathrm{SC}<5 \%$ was an independent predictor of recurrence [hazard ratio $(\mathrm{HR})=101.54, p<0.01$ ]. In addition, the multivariate analysis for PFS showed that patients with areas of SC $<5 \%$ had worse prognostic outcomes than those without (Table III) $(\mathrm{HR}=62.34, p<0.01)$.
Table III. Multivariate analysis of progression-free survival in patients with grade 1 endometrioid carcinoma at FIGO stage IA.

\begin{tabular}{|c|c|c|c|}
\hline Variables & Hazard ratio & $(95 \% \mathrm{CI})$ & $p$-Value \\
\hline \multicolumn{4}{|l|}{ Peritoneal washing cytology } \\
\hline Positive vs. Negative & 2.34 & $(0.07-30.87)$ & 0.62 \\
\hline \multicolumn{4}{|l|}{ Mode of uterine resection } \\
\hline $\begin{array}{l}\text { Extended hysterectomy } v s \text {. } \\
\text { Simple hysterectomy }\end{array}$ & 0.46 & $(0.02-3.49)$ & 0.46 \\
\hline \multicolumn{4}{|l|}{ Para-aortic lymphoadenectomy } \\
\hline Performed vs. Not performed & 0.75 & $(0.02-10.16)$ & 0.81 \\
\hline \multicolumn{4}{|l|}{ Area of serous carcinoma $<5 \%$} \\
\hline Positive $v s$. Negative & 62.34 & $(9.99-485.02)$ & $<0.01$ \\
\hline
\end{tabular}

Detailed clinical information concerning the cases with recurrences is shown in Table IV. Three cases of EG1 with areas of SC $<5 \%$ recurred at distant sites. Conversely, two cases with pure-type EG1 recurred at the vaginal stump.

\section{Discussion}

Among several histological subtypes, endometrial SC had the worst prognosis (15). Mixed carcinoma with SC had a similar clinical outcome to pure-type SC $(16,17)$. Also, the Cancer Genome Atlas shows that many SCs have high copy number alterations and worse prognosis (18). Thus, SC and endometrial carcinoma mixed with SC are poor prognostic histological subtypes. These studies defined mixed carcinoma with an area of SC $<5 \%$ as type I tumor, according to the 2014 WHO criteria (12). However, few studies have examined 
Table IV. Details of the 5 patients with recurrence.

\begin{tabular}{|c|c|c|c|c|c|c|c|c|}
\hline $\begin{array}{l}\text { Case } \\
\text { number }\end{array}$ & Age & Histology & Surgery & Adjuvant & $\begin{array}{l}\text { Place of } \\
\text { therapy }\end{array}$ & $\begin{array}{l}\text { Therapy for } \\
\text { recurrence }\end{array}$ & $\begin{array}{l}\text { Time from } \\
\text { recurrence }\end{array}$ & $\begin{array}{l}\text { Outcome } \\
\text { primary treatment } \\
\text { until recurrence }\end{array}$ \\
\hline 1 & 70 & $\begin{array}{c}\text { EG1 with }<5 \% \\
\text { serous carcinoma }\end{array}$ & $\begin{array}{c}\text { Simple } \\
\text { hysterectomy+ } \\
\text { pelvic } \\
\text { lymphadenectomy }\end{array}$ & $\begin{array}{c}\text { Not } \\
\text { performed }\end{array}$ & $\begin{array}{l}\text { Vaginal stump+ } \\
\text { Spleen } \\
\text { metastasis }\end{array}$ & $\begin{array}{c}\text { Tumor } \\
\text { resection at } \\
\text { vaginal stump+ } \\
\text { chemotherapy }\end{array}$ & 26 & $\begin{array}{l}\text { Alive with disease } \\
\text { for } 26 \text { months }\end{array}$ \\
\hline 2 & 62 & $\begin{array}{l}\text { EG1 with }<5 \% \\
\text { serous carcinoma }\end{array}$ & $\begin{array}{c}\text { Simple } \\
\text { hysterectomy+ } \\
\text { pelvic } \\
\text { lymphadenectomy }\end{array}$ & $\begin{array}{c}\text { Not } \\
\text { performed }\end{array}$ & $\begin{array}{l}\text { Paraaortic } \\
\text { lymph node }\end{array}$ & $\begin{array}{c}\text { Tumor } \\
\text { resection+ } \\
\text { chemotherapy }\end{array}$ & 48 & $\begin{array}{l}\text { Alive without disease } \\
\text { for } 85 \text { months }\end{array}$ \\
\hline 3 & 65 & $\begin{array}{l}\text { EG1 with }<5 \% \\
\text { serous carcinoma }\end{array}$ & $\begin{array}{c}\text { Simple } \\
\text { hysterectomy+ } \\
\text { pelvic } \\
\text { lymphadenectomy }\end{array}$ & $\begin{array}{c}\text { Not } \\
\text { performed }\end{array}$ & $\begin{array}{l}\text { Multiple } \\
\text { peritoneal } \\
\text { metastasis }\end{array}$ & Chemotherapy & 11 & $\begin{array}{l}\text { Alive with disease } \\
\text { for } 52 \text { months }\end{array}$ \\
\hline 4 & 69 & Pure-type EG1 & $\begin{array}{c}\text { Extended } \\
\text { hysterectomy+ } \\
\text { pelvic } \\
\text { lymphadenectomy }\end{array}$ & $\begin{array}{c}\text { Not } \\
\text { performed }\end{array}$ & $\begin{array}{l}\text { Vaginal } \\
\text { stump }\end{array}$ & $\begin{array}{l}\text { Tumor } \\
\text { resection }\end{array}$ & 60 & $\begin{array}{l}\text { Alive without disease } \\
\text { for } 73 \text { months }\end{array}$ \\
\hline 5 & 72 & Pure-type EG1 & $\begin{array}{c}\text { Simple } \\
\text { hysterectomy+ } \\
\text { pelvic } \\
\text { lymphadenectomy }\end{array}$ & $\begin{array}{c}\text { Not } \\
\text { performed }\end{array}$ & $\begin{array}{l}\text { Vaginal } \\
\text { stump }\end{array}$ & Radiotherapy & 18 & $\begin{array}{l}\text { Death from disease } \\
\text { after } 43 \text { months }\end{array}$ \\
\hline
\end{tabular}

whether endometrial carcinoma with an area of SC $<5 \%$ would be an aggressive tumor. Our previous report, which was a single-institutional study, showed that EG1 with an area of $\mathrm{SC}<5 \%$ had a higher recurrence capacity than pure-type EG1 (14). Similarly, this multi-institutional study showed that an area of SC $<5 \%$ was a recurrent risk factor and a worse factor of PFS than pure-type EG1 at stage IA. This result suggests that an area of $\mathrm{SC}<5 \%$ in endometrial carcinomas is a significant histological feature, which supports the 2020 WHO criteria (13).

In this study, the recurrent rates of EG1 with areas of SC $<5 \%$ and pure-type EG1 were $50 \%$ and $1 \%$, respectively. Many reports have suggested that cases with EG1 at stage IA only require surgery and that adjuvant therapy is unnecessary $(3,4,6)$. However, while the recurrence rate for pure-type EG1 is extremely low, adjuvant therapy might be appropriate for patients with areas of SC $<5 \%$. However, our study could not indicate the effect of adjuvant therapy for these patients. Future studies are needed to examine this further.

The diagnosis of endometrial SC has been useful for immunohistochemical analysis using p53 (19). However, the diagnosis of areas of SC $<5 \%$ might be difficult because, as our previous report revealed, two-fifths $(40 \%)$ of the EG1 cases with areas $\mathrm{SC}<5 \%$ were immunohistochemically positive for p53 (14). In fact, $45 \%$ of endometrial SC had cells that strongly expressed p53 at a rate of $100 \%$ (20). Therefore, since areas of $<5 \%$ SC are extremely small foci, the diagnosis should be performed very carefully. Additionally, considering that many SCs have a p53 mutation, p53 mutation analyses might be needed for a more precise diagnosis (18).

Even though our study was multi-institutional, one limitation was its retrospective design. However, by considering areas of SC $<5 \%$, which was an adaptation of the 2020 WHO criteria, patients needing adjuvant therapy may more easily be identified, and post-treatment follow-up schedules could be tailored individually.

In conclusion, our study showed that EG1 with areas of SC $<5 \%$ had more aggressive histological subtypes than pure-type EG1 at stage IA. Although the exact diagnosis of areas of SC $<5 \%$ was difficult due to small foci, we should pay attention to diagnose because it was important to decide the treatment. Our results may therefore be useful in clinical practice.

\section{Conflicts of Interest}

The Authors declare that they have no conflicts of interest.

\section{Authors' Contributions}

Conception and design: $\mathrm{MM}$ and MT. Data collection or management: AS, TK, YK, KI, and KK. Analysis and interpretation of data: MM, HT, HM, HI, HI, TH, and RS. Drafting the article and revising: MM and MT. 


\section{Acknowledgements}

The Authors would like to thank Editage (www.editage.jp) for English language editing.

\section{References}

1 McAlpine JN, Temkin SM and Mackay HJ: Endometrial cancer: Not your grandmother's cancer. Cancer 122(18): 2787-2798, 2016. PMID: 27308732. DOI: $10.1002 /$ cncr.30094

2 Lewin SN, Herzog TJ, Medel NIB, Deutsch I, Burke WM, Sun $\mathrm{X}$ and Wright JD: Comparative performance of the 2009 international Federation of gynecology and obstetrics' staging system for uterine corpus cancer. Obstet Gynecol 116(5): 11411149, 2010. PMID: 20966700. DOI: 10.1097/AOG. 0b013e3 $181 f 39849$

3 Morice P, Leary A, Creutzberg C, Abu-Rustum N and Darai E: Endometrial cancer. Lancet 387(10023): 1094-1108, 2016. PMID: 26354523. DOI: 10.1016/S0140-6736(15)00130-0

4 Creutzberg CL, van Putten WL, Koper PC, Lybeert ML, Jobsen JJ, Wárlám-Rodenhuis CC, De Winter KA, Lutgens LC, van den Bergh AC, van de Steen-Banasik E, Beerman H and van Lent M: Surgery and postoperative radiotherapy versus surgery alone for patients with stage-1 endometrial carcinoma: multicentre and omized trial. Lancet 355(9213): 1404-1411, 2000. PMID: 10791524. DOI: 10.1016/s0140-6736(00)02139-5

5 Keys HM, Roberts JA, Brunetto VL, Zaino RJ, Spirtos NM, Bloss JD, Pearlman A, Maiman MA, Bell JG and Gynecologic Oncology Group: A phase III trial of surgery with or without adjunctive external pelvic radiation therapy in intermediate risk endometrial adenocarcinoma: a Gynecologic Oncology Group study. Gynecol Oncol 92(3): 744-751, 2004. PMID: 14984936. DOI: 10.1016/j.ygyno.2003.11.048

6 Colombo N, Preti E, Landoni F, Carinelli S, Colombo A, Marini $\mathrm{C}$ and Sessa C; ESMO Guidelines Working Group: Endometrial cancer: ESMO Clinical Practice Guidelines for diagnosis, treatment and follow-up. Ann Oncol 24(Suppl 6): vi33-38, 2014. PMID: 24078661. DOI: 10.1093/annonc/mdt353

7 Bendifallah S, Canlorbe G, Raimond E, Hudry D, Coutant C, Graesslin O, Touboul C, Huguet F, Cortez A, Daraï E and Ballester M: A clue towards improving the European Society of Medical Oncology risk group classification in apparent early stage endometrial cancer? Impact of lymphovascular space invasion. Br J Cancer 110(11): 2640-2646, 2014. PMID: 24809776. DOI: 10.1038/bjc.2014.237

8 Todo Y, Kato H, Kaneuchi M, Watari H, Takeda M and Sakuragi $\mathrm{N}$ : Survival effect of para-aortic lymphadenectomy in endometrial cancer (SEPAL study): a retrospective cohort analysis. Lancet 375(9721): 1165-1172, 2010. PMID: 20188410. DOI: 10.1016/S0140-6736(09)62002-X

9 Fung-Kee-Fung M, Dodge J, Elit L, Lukka H, Chambers A and Oliver T: Cancer Care Ontario Program in Evidence-based Care Gynecology Cancer Disease Site Group. Follow-up after primary therapy for endometrial cancer: a systematic review. Gynecol Oncol 101(3): 520-529, 2016. DOI: 10.1016/j.ygyno. 2006.02.011

10 Fader AN, Starks D, Gehrig PA, Secord AA, Frasure HE, O'Malley DM, Tuller ER, Rose PG, Havrilesky LJ, Moore KN, Huh WK, Axtell AE, Kelley JL, Zanotti KM and UPSC Consortium: An updated clinicopathologic study of early-stage uterine papillary serous carcinoma (UPSC). Gynecol Oncol 115(2): 244-248, 2009. PMID: 19712966. DOI: 10.1016/j.ygyno. 2009.07.030

11 Faratian D, Stillie A, Busby-Earle RM, Cowie VJ and Monaghan $\mathrm{H}$ : A review of the pathology and management of uterine papillary serous carcinoma and correlation with outcome. Int J Gynecol Cancer 16(3): 972-978, 2006. PMID: 16803471. DOI: 10.1111/j.1525-1438.2006.00576.x

12 Kurman, RJ, Carcangiu, ML, Herrington, CS and Young RH: WHO Classification of Tumours of Female Reproductive Organs. $4^{\text {th }}$ ed. Lyon: International Agency for Research on Cancer, pp. 122-154, 2014.

13 WHO Classification of Tumors Editorial Board: Female Genital Organs. $5^{\text {th }}$ ed. Lyon: International Agency for Research on Cancer, pp. 246-308, 2020.

14 Miyamoto M, Takano M, Tsuda H, Soyama H, Aoyama T, Ishibashi $\mathrm{H}$, Kato K, Iwahashi H, Matuura H, Yoshikawa T, Suzuki A, Hirata J and Furuya K: Small foci of serous component as a predictor of recurrence and prognosis for stage IA endometrial carcinomas. Oncology 93(1): 29-35, 2017. PMID: 28259868. DOI: 10.1159/000459625

15 Hamilton CA, Cheung MK, Osann K, Chen L, Teng NN, Longacre TA, Powell MA, Hendrickson MR, Kapp DS and Chan JK: Uterine papillary serous and clear cell carcinomas predict for poorer survival compared to grade 3 endometrioid corpus cancers. Br J Cancer 94(5): 642-646, 2006. PMID: 16495918. DOI: $10.1038 /$ sj.bjc.6603012

16 Fader AN, Starks D, Gehrig PA, Secord AA, Frasure HE, O'Malley DM, Tuller ER, Rose PG, Havrilesky LJ, Moore KN, Huh WK, Axtell AE, Kelley JL, Zanotti KM and UPSC Consortium: An updated clinicopathologic study of early-stage uterine papillary serous carcinoma (UPSC). Gynecol Oncol 115(2): 244-248, 2009. PMID: 19712966. DOI: 10.1016/j.ygyno. 2009.07.030

17 Slomovitz BM, Burke TW, Eifel PJ, Ramondetta LM, Silva EG, Jhingran A, Oh JC, Atkinson EN, Broaddus RR, Gershenson DM and Lu KH: Uterine papillary serous carcinoma (UPSC): a single institution review of 129 cases. Gynecol Oncol 91(3): 463-469, 2003. PMID: 14675663. DOI: 10.1016/j.ygyno.2003.08.018

18 Cancer Genome Atlas Research Network, Kandoth C, Schultz N, Cherniack AD, Akbani R, Liu Y, Shen H, Robertson AG, Pashtan I, Shen R, Benz CC, Yau C, Laird PW, Ding L, Zhang W, Mills GB, Kucherlapati R, Mardis ER and Levine DA: Integrated genomic characterization of endometrial carcinoma. Nature 497(7447): 6773, 2013. PMID: 23636398. DOI: 10.1038/nature12113

19 Chen W, Husain A, Nelson GS, Rambau PF, Liu S, Lee CH, Lee S, Duggan MA and Köbel M: Immunohistochemical profiling of endometrial serous carcinoma. Int J Gynecol Pathol 36(2): 128139, 2017. PMID: 27167671. DOI: 10.1097/PGP.00000000 00000291

20 Chiesa-Vottero AG, Malpica A, Deavers MT, Broaddus R, Nuovo GJ and Silva EG: Immunohistochemical overexpression of p16 and p53 in uterine serous carcinoma and ovarian highgrade serous carcinoma. Int J Gynecol Pathol 26(3): 328-333, 2007. PMID: 17581420. DOI: 10.1097/01.pgp.0000235065. 31301.3e

Received December 19, 2020

Revised January 9, 2021

Accepted January 12, 2021 